\title{
STRUCTURE OF POLYCRYSTALLINE DIAMOND COATINGS DEPOSITED BY CVD METHOD IN THE PLASMA OF GLOW DISCHARGE WITH THE USE OF PULSE POWER SUPPLY
}

\author{
K.I. Koshevoy, Yu.Ya. Volkov, V.E. Strel'nitskij, E.N. Reshetnyak \\ National Science Center "Kharkov Institute of Physics and Technology", \\ Kharkiv, Ukraine \\ E-mail: strelnitskij@kipt.kharkov.ua
}

The structure of CVD carbon coatings synthesized in a hydrogen-methane mixture in the plasma of a glow discharge stabilized by a magnetic field using a pulsed power supply was studied by X-ray diffraction analysis and optical microscopy. The range of deposition parameters is determined, which ensure formation of polycrystalline diamond coatings. The coatings consist of diamond crystals with a clearly defined cut and the crystal lattice parameter close to the tabular value for natural diamond. The influence of the methane partial pressure in the gas mixture and the substrate temperature on the size and predominant orientation of diamond crystals in the coatings was determined. It is established that the use of the pulse mode and grounding of the substrate holder helps to improve the quality of diamond coatings.

\section{INTRODUCTION}

Diamond deposited by Chemical Vapor Deposition (CVD) covers a wide range of synthetic diamond materials with a wide variety of properties such as high hardness, elasticity modulus, thermal conductivity, low friction coefficient, significant range of changes in electrical characteristics, chemical inertness, biocompatibility, thermal and radiation resistance. Polycrystalline diamond in the form of thin films and coatings is becoming increasingly popular in electronics, mechanical engineering, chemical production, optics, nuclear power, medicine and other fields of science and technology, including for hard applications involving extreme high speeds, loads, temperatures and aggressive environment [1-3].

In the CVD process diamond is synthesized from a gas mixture of hydrogen and hydrocarbon (usually methane) in the region of thermodynamic stability of graphite. Atomic hydrogen and methyl radicals play a key role in the growth of diamond. For their formation it is necessary to activate the gas mixture. In the first successful experiments of diamond growth, this was achieved by the method of hot filament - heating the gas with tungsten wire [1]. Since then, many methods of activating the gas mixture using microwave plasma, arc plasmatrons, glow discharge, etc. have been developed and improved. The main parameters that determine the process of CVD diamond are: gas mixture pressure, excitation power (which determines the gas temperature), the proportion of hydrocarbons in the gas mixture and the substrate temperature. Each method of activation has both advantages and disadvantages. Further development of industrial synthesis technologies is aimed at ensuring the best price/quality ratio by increasing the growth rate of diamond films and deposition area, reducing the energy consumption of the process and gas consumption, as well as achieving stability and reproducibility of the synthesis process. First of all the main directions of research are connected with improvement of systems of plasma excitation and their power supplies, and also with increase the general power of the equipment [3].

Currently, for the activation of the working gas is most often used microwave discharge, for the implementation of which requires quite expensive and complex equipment. Significantly simplify and reduce the cost of the synthesis method allows the use of a glow discharge to excite the gas mixture. In this case, the substrate for the CVD diamond is located on the anode, to which an electric potential is applied relative to the cathode. The area of the growing diamond film is limited by the size of the electrodes and the power of the electric supplies [4-6].

In Ukraine work on the synthesis of diamond coatings is carried out at the National Science Center "Kharkov Institute of Physics and Technology", where the original equipment and deposition method of polycrystalline diamond coatings by DC glow discharge, stabilized by a transverse magnetic field have been developed [7-12]. The rotation of the current channel in a magnetic field allows to provide a high current density (more than $1 \mathrm{~A} / \mathrm{cm}^{2}$ ) and makes it possible to deposit the diamond coatings with a thickness in the range from several to hundreds microns on a fairly large area. The work to upgrade existing equipment has been carried out last years. The design of the anode was changed and its grounding was implemented in order to eliminate the presence of a negative floating potential on the substrate holder, which in the previous design reached several hundred volts. High potential can have a negative effect on the deposition rate of coatings and their quality. The geometric dimensions and location of the electrodes are optimized to ensure the stability of the discharge combustion. It is shown that due to the change of the constructive scheme of activation of the gaseous medium the synthesis of diamond films with high characteristics can be carried out with a significant reduction of energy consumption [13, 14].

The next stage of work to increase the productivity of the method was the replacement of the DC power 
supply for the excitation of the glow discharge on pulse one. According to the literature, the use of pulsed power supplies to excite microwave plasma leads to an increase in the growth rate of diamond coatings without increasing the average discharge power [15] while maintaining the quality of the coatings. In [16] we showed that in the case of excitation of a gas environment by a glow discharge, a similar effect can be obtained in terms of increasing the coatings growth rate, however, the structure of the coatings requires more careful study.

The aim of this work was to study the effect of deposition parameters on the structure of polycrystalline diamond coatings synthesized on upgraded equipment by the CVD method in the glow discharge plasma using a pulse power supply.

\section{RESEARCH METHODOLOGY}

CVD diamond coatings were deposited in a glow discharge stabilized by a magnetic field in a mixture of $\mathrm{H}_{2}$ and $\mathrm{CH}_{4}$ on the equipment described in [7-9]. In these studies, a combined disc cathode $\varnothing 115 \mathrm{~mm}$ and a substrate holder $\varnothing 52 \mathrm{~mm}$ were used. The DC power source was replaced by a pulse power supply Tru Plasma Bios 4018. The parameters of the power supply during the coatings deposition were the follows: frequency of $50 \mathrm{kHz}$; duty cycle of 1.1 . The use of pulse power supply has shown that the stability of the discharge compared to DC mode is much higher. This allows increasing the average power supplied to the discharge without the risk of the glow discharge compression or its transition to the arc. In these experiments, the average power was of $2.5 \ldots 3.0 \mathrm{~kW}$ at a glow discharge current of 3.5...4.5 A. As substrates were used plates of monocrystalline silicon with an orientation (111) and dimensions of $7.0 \times 7.0 \times 0.5 \mathrm{~mm}$. To enhance the crystals nucleation before coating deposition, the substrate surface was subjected to machining with diamond powder ACM 2/3. The coating was deposited at different $\mathrm{CH}_{4}$ content in the hydrogenmethane mixture in the range of $1.5 \ldots 3.0 \%$ and two values of total pressure $-16 \cdot 10^{3}$ and $21 \cdot 10^{3} \mathrm{~Pa}$. Thus, the partial pressure of $\mathrm{CH}_{4}$ in the vacuum chamber was in the range of $(3.2 \ldots 4.8) \cdot 10^{2} \mathrm{~Pa}$. The temperature of the samples during the coating deposition, which varied in the range of $955 \ldots 1160{ }^{\circ} \mathrm{C}$, was measured with an optical pyrometer "Promin". The total deposition time of the coatings is $8 \ldots 9 \mathrm{~h}$. The thickness of the coatings, which was determined by the increase in mass per unit area of the substrate, was in the range of $20 \ldots 30 \mu \mathrm{m}$ at a gas pressure in the chamber of $16 \cdot 10^{3} \mathrm{~Pa}$ and $30 \ldots 40 \mu \mathrm{m}$ at a pressure of $21 \cdot 10^{3} \mathrm{~Pa}$.

The study of the phase composition, texture and substructure of coatings was performed by X-ray diffraction analysis. Diffractograms were taken on a DRON-3 apparatus in filtered radiation from a copper anode in a Bragg-Brentano focusing scheme $\theta-2 \theta$. The average size of the coherent scattering regions (CSR) of diamond in the films was determined by the SelyakovScherrer formula based on the expansion of the diffraction line (111) of diamond, taking into account the expansion of the standard. Texture analysis was performed by calculating texture coefficients from the ratio:

$$
T_{C}=\left[n I_{m}^{(h k l)} / I_{0}^{(h k l)}\right] /\left[\sum I_{m}^{(h k l)} / I_{0}^{(h k l)}\right],
$$

where $I_{m}{ }^{(h k l)}$ is the integral reflection intensity $(h k l)$; $I_{0}^{(h k l)} \quad$ - value of reflection intensity $(h k l)$ for nontextured powder material; $n$ is the number of reflected reflections.

The morphology of the surface of diamond coatings was examined using an optical microscope MET-1.

\section{RESULTS AND DISCUSSIONS}

According to the results of X-ray diffractometry in the synthesized coatings in the selected range of deposition parameters (regardless of the pressure, composition of the gas phase and substrate temperature) a polycrystalline diamond (cubic space group Fm3m) was formed. No other phases were detected, including signs of crystalline or amorphous graphite. These data are confirmed by characteristic microscopic images of the coating surface, which show only diamond crystals with a well-defined faceting and sizes in the range of $5 \ldots 20 \mu \mathrm{m}$. It is determined that the coatings structure obtained using a pulse power supply is similar to the structure of diamond films obtained by DC glow discharge [11-13]. The diffraction pattern of one of the samples is shown in Fig. 1. The diamond lines are intense, narrow, and each is represented by two doublet lines $K \alpha_{1}$ and $K \alpha_{2}$ (see Fig. 1,b). The selection of the doublet showed that the diamond lines are quite symmetrical (see Fig. 1,c), which indicates the absence of a significant number of defects in the crystal structure.

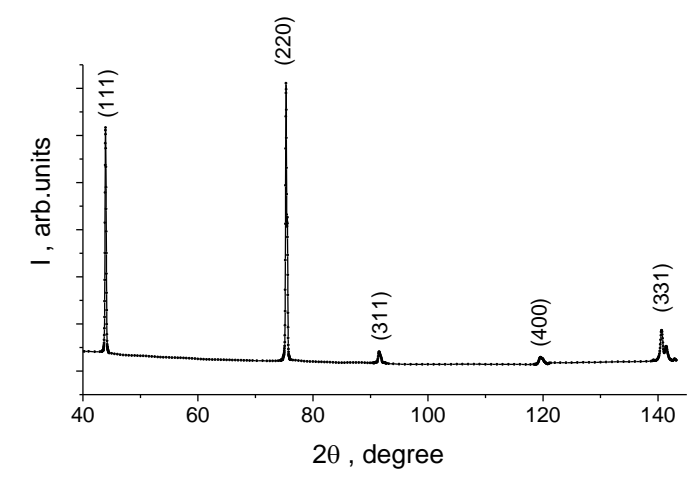

$a$

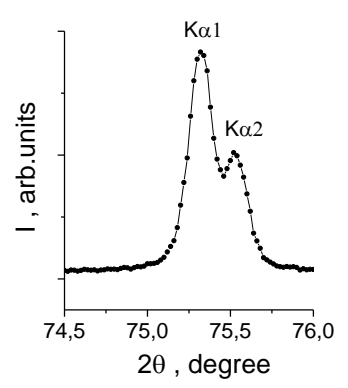

$b$

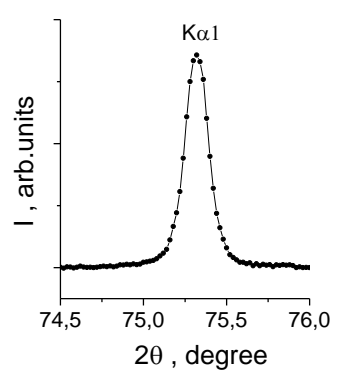

$c$
Fig. 1. X-ray diffraction pattern of diamond coating (a) deposited under partial $\mathrm{CH}_{4}$ pressure of $3.2 \cdot 10^{2} \mathrm{~Pa}$ and substrate temperature of $1130^{\circ} \mathrm{C}$. Reflection (220) before (b) and after (c) the selection of the doublet 
According to the angular position of the diffraction lines, the parameter of the crystal lattice of diamond in the coatings was calculated. The obtained values were in the range of $0.3565 \ldots 0.3566 \mathrm{~nm}$, which is close to the tabular value for natural diamond ( $a=0.35667 \mathrm{~nm})$ [17]. The obtained data indicate high crystallinity and purity of the synthesized polycrystalline diamond coatings.

The results of calculations of the CSR size of diamond in the coatings are shown in Fig. 2. It is seen that the size of CSR is in the range of $38 \ldots 240 \mathrm{~nm}$. As the temperature of the substrate increases during deposition, the size of the CSR increases nonlinearly. In films deposited at a pressure of $21 \cdot 10^{3} \mathrm{~Pa}$ and the lowest content of $\mathrm{CH}_{4}$ in a hydrogen-methane mixture of $1.5 \%$ the size of the CSR is approximately 1.5 times greater than at a $\mathrm{CH}_{4}$ content of $2 \%$. Similar dependences are observed at a pressure of $16 \cdot 10^{3} \mathrm{~Pa}$. With an increase in methane content from 2 to $3 \%$ the size of the CSR decreases almost 2 times. The generalization of the results allowed us to establish that the experimental points in Fig. 2 fit well on the common curves of the CSR size on the deposition temperature for fixed values of the partial pressure $\mathrm{CH}_{4}$, i.e. at a certain carbon content in the gas. The greatest sizes of diamond CSR from 100 to $240 \mathrm{~nm}$ are observed at the lowest partial pressure of methane $3.2 \cdot 10^{2} \mathrm{~Pa}$.

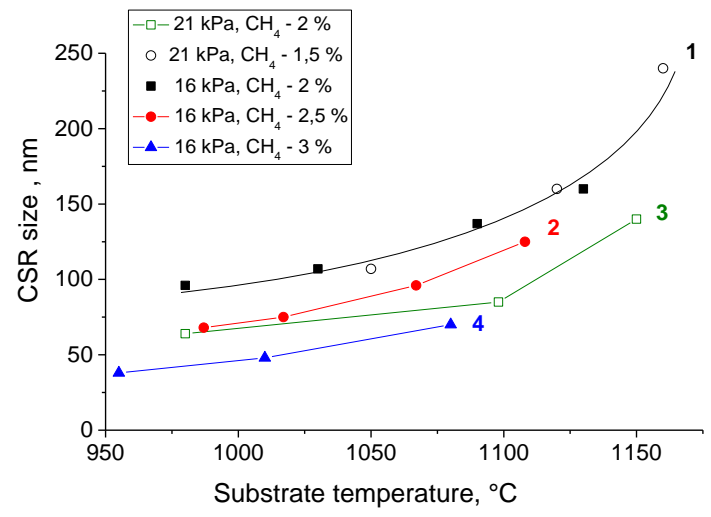

Fig. 2. Dependences of size of diamond CSR on deposition temperature for various values of partial pressure $\mathrm{CH}_{4}$.

$1-3.2 \cdot 10^{2} \mathrm{~Pa} ; 2-4.0 \cdot 10^{2} \mathrm{~Pa}$;

$3-4.2 \cdot 10^{2} \mathrm{~Pa} ; 4-4.8 \cdot 10^{2} \mathrm{~Pa}$

All diamond lines are present on the diffraction patterns of the samples, but the ratio of line intensities differs from the values characteristic of non-textured material. With the chaotic orientation of the crystals the intensity of diffraction for the reflections (220) and (400) is much lower than (111). For most deposited coatings this ratio are not met. The analysis of the texture of diamond coatings was performed by calculating the texture coefficients. The texture coefficient characterizes how many times the probability of coincidence of the normal to the surface of the sample with the normal to the plane $(h k l)$ in the investigated sample differs from that of the chaotic distribution of grains in the non-textured sample.
It is established that the predominant orientation of diamond crystal grains in coatings is significantly influenced by both the synthesis temperature and the pressure and composition of the gas phase. The results of the calculations are summarized in Fig. 3, which shows a map of modes that determine the texture of the coatings. Here is the abscissa in Fig. 3 - partial pressure of methane, the ordinate is the temperature of the substrate. Four zones of modes are marked with solid lines on the map. Within each area the coatings have a similar predominant orientation. The figure for each zone shows a typical distribution of texture coefficients. The largest is zone 1, which in the region of low temperatures extends over the entire investigated range of methane pressure and has a rather complex shape. For samples of this zone, the value of the texture coefficient for reflection (400) significantly prevails over the others, ie most diamond crystallites are oriented by the axis of type $\langle 100\rangle$ in the direction normal to the film surface. This texture is most pronounced in coatings deposited at a partial pressure of methane of $4.2 \cdot 10^{3} \mathrm{~Pa}$ and a substrate temperature of 980 and of $1098^{\circ} \mathrm{C}$ (the area is highlighted by a dashed line in Fig. 3). The morphology of the film surface with this texture indicates that the coating is dominated by crystals with square facets (Fig. 4,a).

An increase in the substrate temperature, regardless of the pressure and methane content during synthesis, leads to a gradual decrease in the textural coefficient for reflection (400) and an increase in the coefficients for other reflections. In zone 2 , which corresponds to a partial pressure of $(3.2 \ldots 4) \cdot 10^{2} \mathrm{~Pa}$ and a temperature within $1050 \ldots 1160{ }^{\circ} \mathrm{C}$ the coefficient for reflection (111) predominates. The textural axis in coating changed on $\langle 111\rangle$. Crystals with triangular facets predominate on the coating surface (see Fig. 4,b). A further increase in temperature leads to an increase in the texture coefficient for reflection (220), i.e. in the samples the location of diamond grains with the axis $\langle 110\rangle$ in the direction normal to the surface of the sample - zone 3 slightly increases. With an increase in the partial pressure of methane to $4.8 \cdot 10^{2} \mathrm{~Pa}$ and the synthesis temperature above $1000{ }^{\circ} \mathrm{C}$ diamond grains in the coatings are distributed almost chaotically - zone 4 .

Thus by changing the partial pressure of methane in the hydrogen-methane mixture and the temperature of the substrate, you can adjust the size of the crystallites and the texture in the diamond coatings. To ensure the texture of the coatings with the axis $\langle 100\rangle$, the deposition temperature should be reduced below $1000{ }^{\circ} \mathrm{C}$. Increasing the partial pressure of methane to $4.8 \cdot 10^{2} \mathrm{~Pa}$ leads to a more chaotic distribution of diamond grain orientations. To ensure the maximum size of the crystallites, the optimal partial pressure of methane is $3.2 \cdot 10^{2} \mathrm{~Pa}$ and the substrate temperature is about $1150{ }^{\circ} \mathrm{C}$.

It should be noted that the results of the experiments are in good agreement with the existing ideas about the mechanisms of growth of polycrystalline diamond coatings and previously obtained data. 


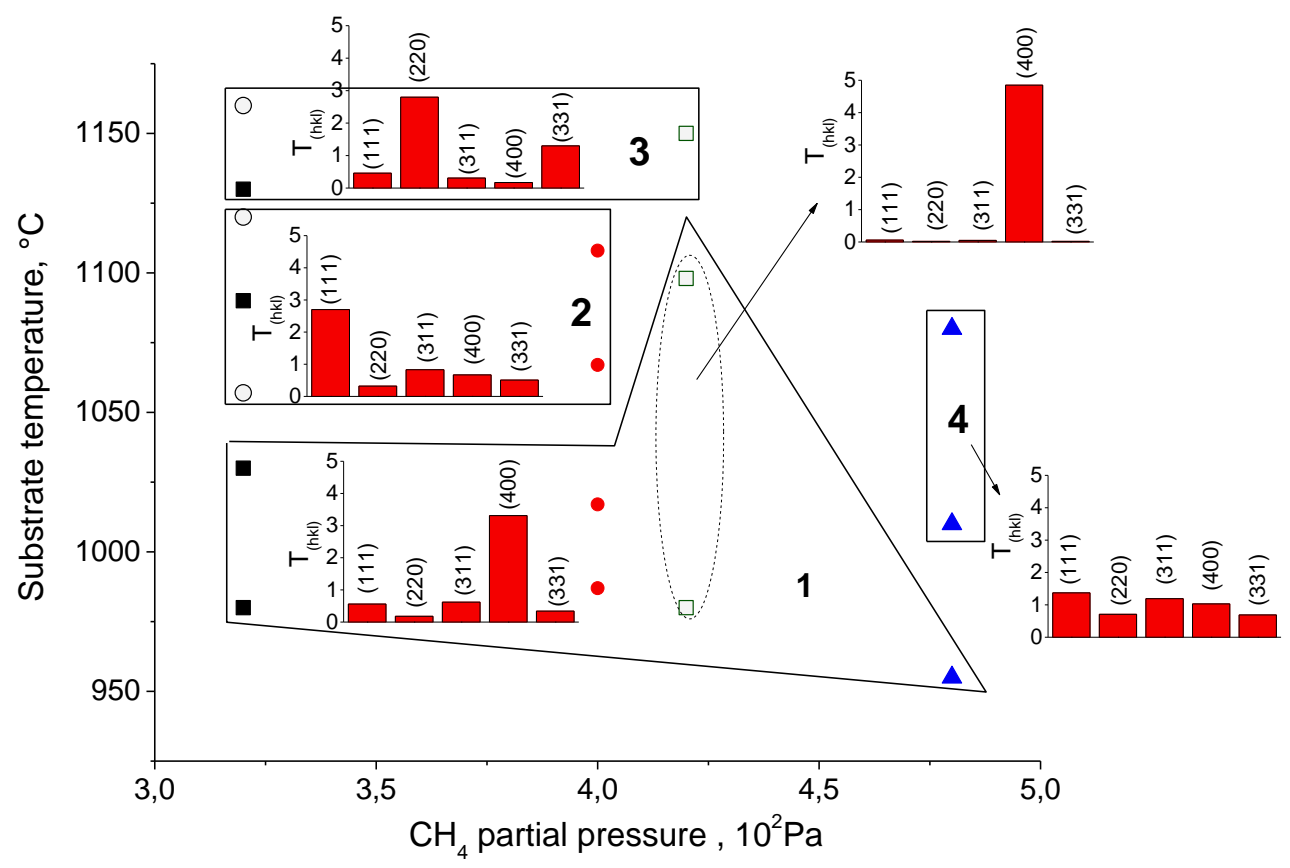

Fig. 3. Map of modes that determine the texture in diamond coatings. A typical distribution of texture coefficients is given for each zone. Axis of predominant orientation of diamond crystallites:

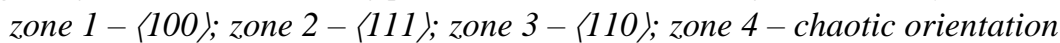

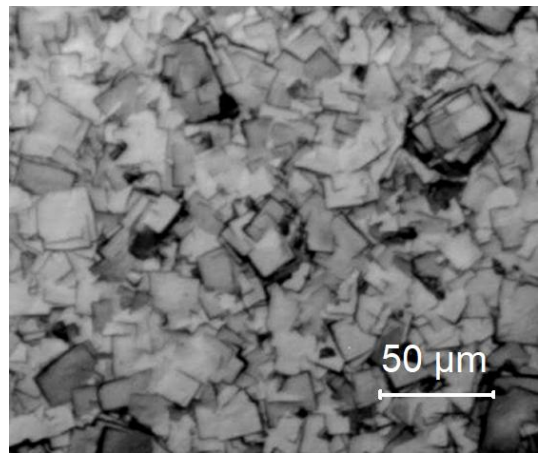

$a$

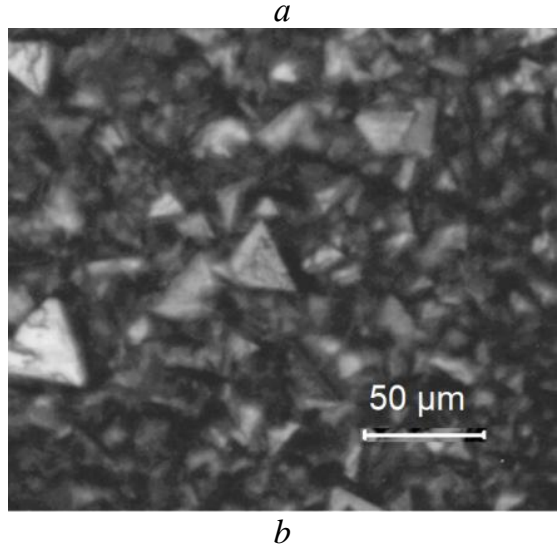

Fig. 4. Microscopic images of the surface of diamond coatings with different textures: $a$ - texture with an axis $\langle 100\rangle$, dominated crystals with square facets; $b$-texture with an axis $\langle 111\rangle$, dominated crystals with triangular facets

It is known that the structure of the diamond film is determined by the density of the centers of diamond nucleation and growth time. The diamond nuclei formed on the substrate grow and close in CVD processes. After conjunction of the crystallites, the growth of the polycrystalline film occurs according to the model of competitive growth of grains by Van der Drift. The orientation of small diamond grains before conjunction is almost random. After conjunction the crystals the orientation of the individual grains becomes more regular. The crystals with the highest growth continue to grow due to less favorably oriented crystals. As it grows a limited number of crystallites survive, which lead to the formation of sufficiently dense columnar highly textured films. As the film thickness increases, the grain size and the degree of texture perfection increase slightly [18].

Wild and co-authors [19] introduced the growth parameter $\alpha$, which shows the ratio the growth rates $\left(V_{\text {uvw }}\right)$ along different axes of crystals: $\alpha=3^{1 / 2} V_{100} / V_{111}$. The equilibrium shape of the crystal is determined by the faces with the lowest growth rate. The direction $\langle 111\rangle$ will increase the fastest when $\alpha$ is 1 and the growth morphology is cubic. When $\alpha$ is 3 , the fastest growing direction will be $\langle 100\rangle$, and the growth morphology will be an octahedron. In intermediate cases, the shape of the crystals will be more complex. In practice, it is determined that the main influence on the morphology of the films and the corresponding parameter $\alpha$ have the substrate temperature and the concentration of hydrocarbons in the gas mixture. Some works provide maps of modes that determine the values of the parameters $\alpha$ or surface morphology [20,21]. We believe that the map of the distribution of texture coefficients, which is shown in Fig. 3 is more informative. It is clear that for each of the methods of CVD synthesis of diamond coatings, the distribution of zones on the maps will be significantly different. Thus in coatings deposited using gas excitation by the hot filament method chaotic grain orientation is often present. Samples grown in high density plasma conditions (e.g. using microwave excitation) are usually more textured [22]. 
The authors of [5], who synthesized the coating using a glow discharge, noted that the change in the morphology and orientation of diamond crystals in the coatings affects the rate of their deposition. According to their data, with the increase of methane content from $0.9 \ldots 1.2$ to $5 \%$, the predominant orientation changes between $\langle 100\rangle$ and $\langle 110\rangle$, and when reaching $7 \%$ the orientation becomes chaotic. The coatings with orientation $\langle 110\rangle$, obtained at a methane content of $4 \%$, have a maximum deposition rate. Unfortunately, the authors did not control the temperature of the substrates during deposition. In our experiments, the increase in methane content leads to an increase in the coatings deposition rate, the stronger the higher the substrate temperature [16]. At the same time, at fixed methane content the dependence of the deposition rate on temperature has a maximum, similar to the data of [5]. We did not find unambiguous correlations between the texture in the coatings and the rate of their deposition

It was shown previously that the average diamond grain size in coatings deposited on diamond powdertreated substrates using DC glow discharge is determined by the density of diamond nucleus and is virtually independent of the deposition temperature [11]. On the contrary, the size of the CSR determined by the X-ray method increases exponentially with increasing temperature. In addition, in contrast to the increase in diamond grain sizes the value of CSR does not change with the thickness of the coatings. Areas of coherent scattering are blocks in the volume of a crystal grain with a sufficiently perfect crystal structure, which are separated by small-angle boundaries. The presence of small-angle boundaries formed by dislocation walls can adversely affect many properties of the material, primarily mechanical, electrical and optical. It is shown that the size of CSR is determined by the ability of dislocations formed in the volume of grains to move, lining up in the dislocation walls, which increases with temperature. In this work, when using the pulse power supply, we obtained similar dependences of the growth of the size of the CSR on the temperature. However, the values of CSR size in 3 times higher, i.e. diamond grains are more perfect. Another factor contributing to the improvement of grain perfection is the grounding of the substrate holder on the upgraded version of the equipment. In the previous version of equipment, the presence of a high floating potential on the insulated substrate holder led to the bombardment of the condensation surface by accelerated ions, which contributed to the formation of structural defects in the crystal lattice of the diamond. Thus, the advantage of using upgraded equipment is not only to increase the growth rate of diamond coatings, but also the ability to improve their quality.

\section{CONCLUSIONS}

The structure of carbon coatings synthesized by the CVD method in a hydrogen-methane mixture in the glow discharge plasma stabilized by a magnetic field using a pulsed power supply has been studied.

It was found that at a partial pressure of methane in the range of $(3.2 \ldots 4.8) \cdot 10^{2} \mathrm{~Pa}$ and substrate temperature from 955 to $1160{ }^{\circ} \mathrm{C}$ coatings consist of diamond crystals up to $20 \mu \mathrm{m}$ with well-defined faceting and the crystal lattice parameter closed to the table value for natural diamond. In most coatings, a texture with a predominant arrangement of diamond grains with an axis $\langle 110\rangle,\langle 111\rangle$ or $\langle 100\rangle$ in the direction normal to the surface of the sample was detected. It is shown that by changing the partial pressure of methane in the hydrogen-methane mixture and the temperature of the substrate, it is possible to adjust the size of the CSR and the texture in the coatings. As the temperature increases, the size of the CSR of the diamond increases nonlinearly, and with increasing partial pressure of methane decreases.

It was proposed the map of coatings deposition modes which showing the texture depending on the synthesis parameters.

The structure of coatings obtained using a pulse power supply to excite a glow discharge is generally similar to the structure of coatings synthesized in the DC glow discharge.

It was shown that the use of pulsed mode and grounding of the substrate holder improves the perfection of diamond coating.

\section{REFERENCES}

1. M. Prelas, G. Popovici, L. Bigelow. Handbook of industrial diamonds and diamond films. New York: Marcel Dekker, 1998, 1232 p.

2. R.S. Balmer, J.R. Brandon, S.L. Clewes, et al. Chemical vapour deposition synthetic diamond: materials, technology and applications // J. Phys. Condens. Matter. 2009, v. 21, N 36, p. 364221.

3. M. Schwander, K. Partes. A review of diamond synthesis by CVD processes // Diamond and Related Materials. 2011, N 20, p. 1287-1301.

4. K. Suzuki, A. Sawabe, H. Yasuda, et al. Growth of diamond thin films by dc plasma chemical vapor deposition // Appl. Phys. Lett. 1987, N 50, p. 728-729.

5. P. Hartmann, R. Haubner, B. Lux Deposition of thick diamond films by pulsed d.c. glow discharge CVD // Diamond and Related Materials. 1996, N 5, p. 850856.

6. S. Sciortino, S. Lagomarsinoa, F. Pieralli, et al. Polycrystalline diamond synthesis by means of high power pulsed plasma glow discharge CVD // Diamond and Related Materials. 2002, N 11, p. 573-578.

7. O.A. Opalev, V.K. Pashnev, I.K. Kovalchuk, et al. Synthesis of diamond coatings in a glow discharge stabilized by a magnetic field // Problems of Atomic Science and Technology. 2000, N 4, p 158-164.

8. V.K. Pashnev, O.A. Opalev, V.I. Grytsyna, et al. Deposition of diamond coatings using a glow discharge stabilized by a magnetic field // Physical Surface Engineering. 2003, v. 1, N 1, p. 49-55.

9. V.K. Pashnev, V.E. Strel'nitskij, O.A. Opalev, et al. Influence of a Transverse Magnetic Field on the Characteristics of a DC Gas Discharge // Plasma Physics Reports. 2004. v. 30, N 9, p. 15-20.

10. I.I. Vyrovets, V.I. Gritsyna, S.F. Dudnik, et al. $\mathrm{X}$-ray diffraction study of the structure and stress state of diamond coatings obtained in a glow discharge // Problems of Atomic Science and Technology. 2008, N 1, p. 142-146. 
11. I.I. Vyrovets, V.I. Gritsyna, O.A. Opalev, et al. Using micro- and nanodispersive diamond for deposition of polycrystalline diamond films in glow discharge // Physical Surface Engineering. 2007, v. 5, N 1-2, p. 87-93

12. I.I. Vyrovets, V.I. Grytsyna, S.F. Dudnik, et al. Surface morphology and structure of nanocrystalline diamond films deposited in $\mathrm{CH}_{4} / \mathrm{H}_{2} / \mathrm{Ar}$ glow discharge plasma // Functional Materials. 2009, v. 16, N2, p. $155-160$.

13. V.I. Gritsyna, S.F. Dudnik, O.A. Opalev, V.E. Strel'nitskij. Using DC glow discharge for diamond coatings synthesis // Problems of Atomic Science and Technology. 2018, N 1, p. 93-95.

14. V.I. Gritsyna, S.F. Dudnik, O.A. Opalev, et al. Peculiarities of diamond film synthesis by the glow discharge // Problems of Atomic Science and Technology. 2018, N 1, p. 96-100.

15. A.B. Muchnikov, A.L. Vikharev, A.M. Gorbachev, D.B. Radishev. Comparative study of homoepitaxial single crystal diamond growth at continuous and pulsed mode of MPACVD reactor operation // Diamond and Related Materials, 2011, v. 20, N 8, p. 1225-1228.

16. K.I. Koshevoy, Y.Ya. Volkov, V.E. Strel'nitskij, E.N. Reshetnyak. Application of pulse power supply for diamond coatings deposition in glow discharge plasma // Problems of Atomic Science and Technology. 2019, N 1, p. 197-200.

17. J. Singh. Physics of semiconductors and their heterostructures. New York: McGraw-Hill, 1993, $864 \mathrm{p}$.

18. Van der Drift A. Evolutionary selection, a principle governing growth orientation in vapourdeposited layers // Philips Res. Rep. 1967, N 22, p. 267-288.

19. C. Wild, R. Kohl, N. Herres, et al. Oriented CVD diamond films: twin formation, structure and morphology // Diamond and Related Materials. 1994, v. 3, p. 373-381.

20. Y. Yokota, Y. Ando, K. Kobashi, et al. Morphology control of diamond films in the region of $\alpha=1-1.5$ using a $60-\mathrm{kW}$ microwave plasma CVD reactor // Diamond and Related Materials. 2003, N 12, p. 295-297.

21. R. Tu, T. Xu, D. Li, S. Zhang, et al. Morphology and Mechanical Behavior of Diamond Films Fabricated by IH-MPCVD // RSC Adv. 2018, N 8, p. 16061-16068.

22. T. Teraji, T. Taniguchi, S. Koizumi, et al. Chemical vapor deposition of $12 \mathrm{C}$ isotopically enriched Polycrystalline diamond // Jpn. J. Appl. Phys. 2012, N 51, p. 090104 (1-7).

Статья поступила в редакиию 25.02.2021 2.

\section{СТРУКТУРА ПОЛИКРИСТАЛЛИЧЕСКИХ АЛМАЗНЫХ ПОКРЫТИЙ, ОСАЖДЕННЫХ МЕТОДОМ СУD В ПЛАЗМЕ ТЛЕЮЩЕГО РАЗРЯДА, С ИСПОЛЬЗОВАНИЕМ ИМПУЛЬСНОГО ИСТОЧНИКА ПИТАНИЯ}

\section{К.И. Кочевой, Ю.Я. Волков, В.Е. Стрельницкий, Е.Н. Решетняк}

Методами рентгеноструктурного анализа и оптической микроскопии исследована структура CVD углеродных покрытий, синтезируемых в водородно-метановой смеси в плазме тлеющего разряда, стабилизированного магнитным полем, с применением импульсного источника питания. Определен диапазон параметров осаждения, обеспечивающих формирование поликристаллических алмазных покрытий, состоящих из алмазных кристаллов с четко выраженной огранкой и параметром кристаллической решетки, близким к табличному значению для природного алмаза. Выяснено влияние парциального давления метана в газовой смеси и температуры подложки на размер и преимущественную ориентацию кристаллов алмаза в покрытиях. Установлено, что использование импульсного режима и заземленного подложкодержателя способствует улучшению качества покрытий.

\section{СТРУКТУРА ПОЛІКРИСТАЛІЧНИХ АЛМАЗНИХ ПОКРИТТІВ, ОСАДЖЕНИХ МЕТОДОМ СУD У ПЛАЗМІ ТЛІЮЧОГО РОЗРЯДУ, ІЗ ЗАСТОСУВАННЯМ ІМПУЛЬСНОГО ДЖЕРЕЛА ЖИВЛЕННЯ}

\section{К.І. Кочевий, Ю.Я. Волков, В.С. Стрельницький, О.М. Решетняк}

Методами рентгеноструктурного аналізу та оптичної мікроскопії досліджено структуру CVD вуглецевих покриттів, що синтезуються у воднево-метановій суміші в плазмі тліючого розряду, стабілізованого магнітним полем, із застосуванням імпульсного джерела живлення. Визначено діапазон параметрів осадження, що забезпечують формування полікристалічних алмазних покриттів, які складаються з алмазних кристалів 3 чітко вираженою огранкою та параметром кристалічної решітки, близьким до табличної величини для природного алмазу. 3'ясовано впливи парціального тиску метану в газовій суміші i температури підкладки на розмір та переважну орієнтацію кристалів алмазу в покриттях. Встановлено, що застосування імпульсного режиму та заземлення підкладинкотримача сприяє покрашенню якості покриттів. 